\title{
Exclusions and Inclusions on Liputan6.com Demo News: Critical Discourse Analysis Based on Theo Van Leuween's Theory
}

\author{
Husnil Amalia ${ }^{1}$, Novia Juita ${ }^{2}$, and Ngusman Abdul Manaf ${ }^{3}$ \\ \{amaliahusnil73@gmail.com¹, Noviajuita@fbs.unp.ac.id², ngusman@fbs.unp.ac.id ${ }^{3}$ \} \\ ${ }^{1,2,3}$ Faculty of Language and Arts, Universitas Negeri Padang, Indonesia
}

\begin{abstract}
The use of critical theory as a means of measurement in this study due to the issue of workers, students, and demonstrates protesting against rising BBM, and demanding re-election of Mayor, ending in chaos, and anarchism. This study basically emphasizes the point of attention on the figure of workers, students, and demonstrates as who marginalized in liputan6.com. This study is a qualitative approach and descriptive method with a critical discourse analysis method to describe how events and actors are portrayed in the news. Discourse analysis model used is a model of Theo Van Leuween with the aim to detect and investigate how the demonstrators the demonstrators who protested against the increase in fuel prices, and urged the re-election of the mayor marginalized position in a discourse. The research found that there are two types of exclusion that are done, is passivation and nominalization; whereas the inclusion of five types, namely differentiation-indifferentiation, objectivity-abstraction, nominationcategorization, determination-indetermination, and assimilation-individualization.
\end{abstract}

Keywords: Discourse Analysis, Exclusion, Inclusion, Theo Van Leeuwen, Liputan6.com.

\section{Introduction}

The use of incubation strategies Theo Van Leeuwen is often used in research in various countries. Previous research on inclusion strategies has been done by [1], [2], [3], [4], and [5]. [1] is one of those who have done critical research using inclusion strategies in an educational policy discourse in the UK. In his findings he argued that inclusion as a "force" in regulating policy. The policy is based on pursuing equality and justice for children.

In Indonesia alone, research on exclusion and inclusion strategy has been done by [6]. The object of his study is figure of KRL passenger as someone who always marginalized in social life in the Metropolitan section on Harian Compass edition May 2013. He found the phenomenon how to passengers sitting of KRL marginalized position in a discourse. In addition, research on exclusion and inclusion strategies was also undertaken by [7]. This study used descriptive qualitative methods. The results of this study revealed that Kompas did not use the exclusion strategy too, that is, not removing the relevant actor (FPI). Preaching to Kompas more often includes an inclusion strategy, in which FPI is shown as a mass organization that only acts anarchist in carrying out its actions and does not display FPI activities that are positive, such as social activities. 
Based on the explanation above, this study has two objectives, namely: (1) describing the exclusion strategy in the media Liputan6.com in the news about Changing Anarchic, Demo to Reject Fuel Increases. Makassar Police Disbanded and coverage of Hundred Persons Attacking Pekanbaru KPU, Police Tear Gas Shot and (2) describe the inclusion strategy in the media Liputan6.com on the news about Changing Anarchists, Demo of Fuel Reject Up Disbanded Makassar Police and reporting Hundreds of Persons Attacking KPU Pekanbaru, Police Tear Gas Shot.

Speech is social practice, "social practice are socially regulated ways of doing things," as defned by Van Leeuwen . Critical Discourse Analysis (CDA) is an ideology detector. Its practitioners employe different theoretical orientations in uncovering the creeping ideologies and asymmetry in texts they wish to approach. "What unites critical discourse analysis is neither methodology nor theoretical ortodoxy, but a common goal: the critique of the hegemonic discourses and genres that effect inequities, injustices, and oppression in contemporary society [8]."

Mass media is one of the media that uses language as a tool to spread social values in society. The statement is in line with one of the five functions that the mass media has on people's lives, namely supervision, interpretation, interrelation, distribution of values, and entertainment. Of all these functions, the function of spreading values/social functions is the most important and shows the power of mass media in influencing society. Through this social function, the media can pass on certain norms or values to the public .

Based on a deeper view of the relationship of language and mass media in the development of social life, it is seen that language as a basic element in information in the mass media, it becomes a central role in spreading group ideology so that it is hegemony in broad social structures. Language becomes a hidden weapon used by those who have the power to suppress those who experience social inequality. Language and media are the two forces that construct reality. This reality is manifested in the interests of certain centers of authority which are then intertwined with the interests of the survival of the media itself.

In linguistics, there is one branch that focuses attention and study of language in social life, namely discourse analysis. However, this field of discourse analysis has not been touched by linguists. The term discourse analysis has a very diverse understanding, considering this term is used in various fields of science such as social, political, psychological, communication, etc. In the field of language, discourse analysis is the study of the structure of messages in communication. Specifically, discourse analysis is a study of various functions (pragmatics) of language, and analysis of critical discourse.

Among several figures who contributed to the development of CDA, Theo van Leeuwen was one of the CDA experts who offered an analysis model. Theo van Leeuwen's CDA model seeks to detect and examine how a group or person is marginalized in a discourse. This model generally shows how the parties and actors are presented in the news. There are two centers of attention in this model, namely the expenditure process (exclusion), namely the neglect of the parties relating to discourse, and inclusion, namely how the parties involved in the discourse are presented [9].

One of the models carried by experts in the analysis model presented by Theo Van Leeuwen. Specifically, Van Leeuwen revealed that language is a reflection of ideology so that by learning the language reflected in the text, ideology can be exposed. This analysis model is used to detect and examine how a group or a person is marginalized in his position in discourse. How in a dominant group is more holding in interpreting an event and its meaning, while other groups that are in a lower position tend to continue to be made objects of meaning and depicted badly? For example, labor groups, farmers, fishermen, illegal immigrants, and 
women are groups that not only do not have power and power, but also in the discourse of preaching are often described as uneducated, wild, disturbing peace and comfort, and often act anarchically. Here there is a link between discourse and power. Power does not only operate through a series of discourses to define something or a group that is poorly described [10].

In his theory, Theo Van Leeuwen's analysis model is divided into two things, namely the process of exclusion and inclusion. The exclusion process is divided into passivation, nomination, and substitution of clauses. The inclusion process is divided into seven, namely, differentiation-in differentiation, objectivation-abstraction, nomination-categorization, nomination-identification, determination-indetermination, assimilation-individualization and association-disassociation. One of the most important agents in defining a group is mass media. Through the news that is constantly being spread, the media indirectly shapes the understanding and awareness in the minds of the public about something. The discourse created by the media may legitimize one thing or group and delegitimize and marginalize other groups [11].

Van Leeuwen's analysis generally shows how the parties and actors (individuals or groups) are presented in the news. There are two centers of attention. First, the expenditure process (Exclusion). Whether in a news text, some groups or actors appear in the news and what discourse strategies are used for it. The process of bringing up this actor can indirectly change the public's understanding of an issue and legitimize the position of a particular understanding. Second, the process of inclusion (inclusion). If exclusion relates to the question of how the process of a group is excluded in the news text, then inclusion relates to the question of how each party or group is displayed through reporting. Both the processes exclusion and inclusion use what is called a discourse strategy. By using words, sentences, information or formulations of certain sentences, certain ways of telling stories, each group is represented in the text [12].

The limitation of this research is the research on a critical discourse analysis of this news text is limited to the position of exclusion (passivation, and nomination) in the news coverage of differentiation, in differentiation, objectivation-abstraction, nomination-categorization, determination-indetermination, and assimilation-association) in news coverage 6 November 2014 and October 2016 editions. To use the analysis of Theu Van Leeuwen's model we need to know how actors are presented in the news. Two things need to be considered when examining the displayed social actors. First, Exclusion: are the actors displayed or omitted in the news text? If so how is the media doing it? Second, Inclusion: how is the actor displayed, and how is it portrayed in the news?. Even though the actor is not eliminated, the process of marginalizing a person or group can still be done .

Research that studies news reporting strategies like this has been done by several people before. Researchers use references from several such studies, but this study still has the characteristics and differences with previous studies. Similar research related to the research conducted by researchers is as follows.

\section{Methods}

The type of research entitled "Theu Van Leeuwen's Critical Discourse Analysis: Marginalizing Workers/Student Position in the News Demo Action at Liputan6.com November 2014 and October 2016 Edition" is a descriptive study because it aims to describe the main issues then each party or each party or groups involved in the news are displayed (inclusion) or hidden (exclusion). This study uses a qualitative approach because it presents data in the form of words and sentences that are analyzed based on the actual form without 
releasing the context of the surrounding data based on the interpretation of the researcher. Qualitatif is an approach for exlploringand undersnding the meaning individuals or groups ascribe o a social or human problem. The procedur of research involves emerging questions and procedure, data typicaly collected in the paricint's setting, dataanalysis inductively building from particulars to general themes, and the researcher making interprelaions of the meaning of the data. The final wrien report has a flexible structure [13].

The data source of this research was in the form of news discourse from Liputan6.com, November 2014 and October 2016. The data used in this study were in the form of texts relating to the marginalization of workers/students in Liputan 6, April and May 2017. Issues. In this study, the data collection method used to refer to the method because of the data of information in the study directly sourced from the results of listening to the news of the demonstration action contained in the Coverage 6 of November 2014 and October 2016. From this method of referring, the technique used directly was the reading-note technique. The reading technique is done by reading carefully and thoroughly all things that have a characteristic as a form of marginalization of workers/students in a demonstration. After reading activities are carried out, then the recording activities are carried out. The recording activity is carried out by recording the classification of all data based on the position of the perpetrators or parties involved in the news. The research instrument used to support research and facilitate data analysis is the data table. The data found is then entered in the appropriate table.

Table 1. Data Analysis

\begin{tabular}{llcl}
\hline Number & Title of & Text and codes & Strategy Used/ Levels \\
& \\
\hline
\end{tabular}

In this study researchers as instruments of data collection because researchers are tools for collecting data and observers of research data sources. Besides, other research instruments are Liputan 6, November 2014 and October 2016 editions which are used as data sources. This method is used to describe and analyze existing data to describe completely, regularly and thoroughly the object of research (news of sexual harassment). Data analysis techniques in this study include the following steps.

a. The selection of data following the subject of the study is data in the form of news that raises the issue of demonstrations that are displayed in Cover 6 of November 2014 and October 2016 Edition.

b. Data coding uses codes determined by the researcher to facilitate the classification of data based on research problems. The coding of news text data is based on the date, month and year of publication, followed by the first letters of each word in the headline, then ends with the alphabet az which shows some data are taken from the same title, for example (07/11/14/BADTBNDPM/a), the code stated states that the data was taken from Cover 6 which was published on November 7, 2014 with the title "Changed Anarchist, Demand for BBM Refuses to be Disbanded by Makassar Police" and is the first data from the headline.

c. Data description is done by classification based on exclusion (passivation, and nominalization), and Inclusion (inclusion of differentiation-in differentiation, 
objectivation-abstraction, nomination-categorization, determination-indetermination, and assimilation-association) to obtain a description of the marginalization of labor/student/student/abstraction position, nomination-categorization, determinationindetermination, and assimilation-association) to obtain a description of the marginalization of the position of the worker/student/demonstrators in the [14] and [15] edition of Liputan 6.com.

d. Analyze data that has been classified to answer the subject matter of the study and obtain conclusions from the results of the study based on the analysis of critical discourse Theu Van Leeuwen.

\section{Research Results and Discussion}

The results of this study include (1) exclusion strategies in the media Liputan6.com on reporting on Changing Anarchists, Demand for BBM Rejects Disbanded by Makassar Police and Hundreds of People Attacking Pekanbaru KPU, Police Shoot Tear Gas, and (2) inclusion strategy in the media Liputan6.com on the news about the changing news anarchist, the refusal to refuse BBM Up Disbanded by the Makassar Police and the reporting of Hundreds of Persons Attacking KPU Pekanbaru, Police Shoot Tear Gas. This section will describe the results that researchers have obtained after analyzing the data on the two news items mentioned above in the daily Liputan6.com dated November 7, 2014, and October 26, 2016. The results of this study are as follows.

\subsection{Exclusion}

\subsubsection{Passivation}

This strategy discusses the process of how a particular group or actor is not involved or eliminated in discourse to protect himself.

Evidence of the sentence in the news:

The police finally opened fire with tear gas to disperse the demonstrators at the intersection of Jalan Petarani, Makassar, South Sulawesi on Thursday, November 6th this afternoon.

Table 2. Data Analysis of Exclusion (Pasvation)

\begin{tabular}{|l|l|}
\hline Active & The police finally fired tear gas to disperse the demonstrators \\
\hline Passive & demonstrators are given tear gas \\
\hline
\end{tabular}

From the two sentences above it can be concluded that, if a report is presented in an active form, then the social actor or actor can be displayed in the text. However, if the news is presented in a passive form, the social actor or actor is lost. As a result, the focus of the discussion is the victim, not the perpetrator. Then the readers are not critical, they only think of the victims, not the perpetrators, because they have been directed by the media through passive sentences.

\subsubsection{Nominalization}

With the nomination of social actors or groups can be eliminated in a discourse. This strategy is to change the verb (verb) to be a noun (noun) which means an event, usually with 
the effect of "pen". For example, the word raping (verb) in the form of an action or activity, then converted into rape (noun) which means an event.

Evidence in the nomination news text that could eliminate the subject or perpetrator of the action:

Table 3. Data Analysis of Exclusion (Nominalization)

\begin{tabular}{ll}
\hline Verba & The police finally opened tear gas shots to disperse the demonstrators \\
Noun 1 & The air masses demo disband the consequent release of tear gas \\
Noun 2 & the release of tear gas against protesting mass \\
Noun 3 & again the release of tear gas against the masses protesting \\
\hline
\end{tabular}

In verb sentences, between subject and object complement each other so that they can have meaning. Whereas in nouns 1, 2 and 3, the presence of the subject (police) has been removed, then the act of releasing has changed meaning as an event.

\subsection{Inclusion}

\subsubsection{Differentiation-Indifferentiation}

It is a discourse strategy on how a group is cornered by presenting other groups or discourses that are seen as more dominant or better.

Table 4. Data Analysis of Inclusion (Differentiation- Indifferentiation)

$\begin{array}{ll}\text { In differentiation } & \text { Uncontrolled situation, mob attacks police with stones and } \\ \text { Differentiation } & \text { Uncontrolled situation, mob attacks police with stones and } \\ & \text { water. The police tried to repel and tried to calm the crowd, } \\ \text { but the crowd became more determined and attacked the } \\ \text { officers with wood }\end{array}$

In the first sentence, it is clear that the mob attacked the police with stones. Whereas in the second sentence, there is the fact that the police are trying to repel and try to calm down, but the masses are becoming more determined and attacking officers with wood. Indirectly this second sentence there is a difference between the masses who continue to attack the police with the more humane (police) by trying to calm the masses.

This can be said to be marginalizing because the text has separated the position of the masses who attacked the police. Then the facts about why the mob attacked the police are not shown in the text. Instead, the facts about the police trying to calm the masses are displayed in the text.

\subsubsection{Objectivity-Abstraction}

This discourse strategy relates to the question of whether information about an event or social actor is presented by giving concrete (clear) or abstraction (vague) instructions.

Table 5. Data Analysis of Inlusion (Obecivity-Abstraction)

\begin{tabular}{|c|c|}
\hline Objectivity & $\begin{array}{l}\text { hundreds of workers in Subang, West Java also protested against } \\
\text { rising fuel prices at the Regent's Office }\end{array}$ \\
\hline Abstraction & $\begin{array}{l}\text { several students were finally secured because they acted } \\
\text { anarchically and provoked the masses }\end{array}$ \\
\hline
\end{tabular}


In the first sentence, it is clear how many workers demonstrated. While in the second sentence some students still vaguely "some". So the reader will have a different view between the so-called clear with abstraction.

According to Teo Van Leeuwen, mention in the form of abstraction is often caused by journalists' ignorance of clear information, but rather as a journalist's strategy in presenting something.

\subsubsection{Nomination-Categorization}

This strategy often occurs whether the actor or actor is presented as is or categorized (religion, status, physical form, etc.). The category is not very important because generally, it will not affect the meaning to be conveyed to the public. However, it will indirectly give a stamp to that group. Evidence in the news text:

Table 6. Data Analysis of Inclusion (Nomination-Categorization)

\begin{tabular}{ll}
\hline Nomination \\
Categorization
\end{tabular} $\begin{aligned} & \text { hundreds of workers held a convoy to the Grahadi State Building } \\
& \text { Students who became mass provocateurs demonstrated, one of } \\
& \text { whom was named Ershad who was black }\end{aligned}$

Giving the category of "black", is additional information about who the student is. As a result, the public will see that black people are identical to provocation (pitting sheep).

\subsubsection{Determination-indetermination}

Often actors or events in the news delineated or specific, but often portrayed universally as a possible reporter has not received strong evidence to be written. Evidence in the news:

Table 7. Data Analysis of Inclusion (Determination-Indetermination)

\begin{tabular}{ll}
\hline Indetermination & $\begin{array}{l}\text { anarchist action student this is unfortunate because } \\
\text { initially, the students held a protest against the } \\
\text { government's plan to raise the price of subsidized fuel oil. }\end{array}$ \\
\hline Determination & The demonstrators who demonstrated and were injured \\
& were taken by officers to the nearest hospital \\
\hline
\end{tabular}

When the first sentence of the student is mentioned, the meaning designated is specific. However, if called by the demonstrators in the second sentence, the meaning is no longer single but plural.

\subsubsection{Assimilation-Individualization}

Assimilation occurs when social actors are in the community or social groups themselves, not as specific actors. Evidence in the news text:

Table 8. Data Analsis of Inclusion (Assimilation-Individualization)

\begin{tabular}{ll}
\hline Individualization & $\begin{array}{l}\text { Students who became mass provocateurs, one of whom } \\
\text { was named Ershad }\end{array}$ \\
\hline Assimilation & $\begin{array}{l}\text { Police finally opened tear gas fire to disperse the crowd the } \\
\text { demo one }\end{array}$ \\
\hline
\end{tabular}


A first sentence is a form of individualization because there Irsyad categorized students clearly stated. Whereas in the second sentence in the form of assimilation, where one's name is not mentioned but refers to the community called the police, and the masses. The impression that arose from this strategy was that many police fired tear gas. Likewise, with the masses, all the masses seemed to demonstrate.

\section{Conclusion}

Based on the results and discussion that have been presented, it can be concluded several things regarding this research. These things are as follows. Exclusion strategy is the process of releasing an actor, both a person and a group in the news. Several actors often get this treatment from journalists or news writers. This is done with the aim of (1) corner the social actor or actor if what is shown is positive action or activity; or (2) protect or defend the social actor, if what is shown is an act or activity that looks bad or negative. Inclusion strategy is a strategy that seeks to present or present each party or group in certain ways. In this study, researchers found that the selection of speakers also determines the marginalization or corner of a particular group/party. From the news examined, the most widely used strategy is inclusion by displaying actors who are victims in the news.

As for suggestions that researchers can convey, among others (1) given the number of discourse communication strategies that exist and are starting to be used by the media today, the reading community should be able to absorb information critically and carefully, not just swallowing that information outright; (2) not only for readers, media workers should also always try to be neutral, create accurate, accurate, and clear news so as not to cause ambiguity or confusion from an event that can confuse readers; (3) this research is still limited to the media model text strategy or Theo van Leeuwen's approach. Therefore, it is suggested to other researchers to conduct further research related to strategies or approaches from other experts that have not been reviewed in this study; (4) this research was carried out only on one of the print media in the form of electronic media liputan6.com, which focused on two news about Changing Anarchists, Demo of Fuel Reject Up Disbanded by Makassar Police and Hundreds of People Attacking Pekanbaru KPU, Police Tear Gas Shot.

Therefore, other researchers can conduct similar research in other media, both print and electronic media, as well as local or national media, and also on the focus of other news; (5) academics in charge of conducting teaching and learning activities should always update the existing communication theories. Besides, it is hoped that they will not be too much concerned with theory, but rather emphasize relevant examples and increase communication practices so that communication science can be applied in life.

\section{Acknowledgement}

This paper and the research behind it would not have been possible without the exceptional support of my supervisor. His enthusiasm, knowledge and exacting attention to detail have been an inspiration and kept my work on track from my first encounter with the log my paper. Thanks to my supervisor Mrs. Novia Juita and Mr. Ngusman Abdul Manaf, for his direction and guidance. I also thanks to FBS UNP for providing the opportunity, and a place to publish my paper trough ICLEE 2019. I hope this paper is appropriate, passed, and published in the international journal indexed Scopus. 


\section{References}

[1] Hodkinson A.: All Present and Correct? Exclusionary Inclusion Within The English Educational System," Jurnal Critical Education Policy Studies, vol. 11, No. 4, (2013).

[2] Harling M.: Examining The Police: On Inclusion and Investmentality In Swedish Schooling. Jurnal European Education, vol. Vol. 45, No. 3 (2013).

[3] Remley D.: Training within Industry as Short-Sighted Community LiteracyApproprate Training Program: A Case Study of Worker-Centered Training and Its Implications. Jurnal Community Literacy, vol. Vol. 3, No. 2, (2009).

[4] Tange H.: Inclusive and Exclusive Knowledge Practices in Interdisciplinary, International Education. Journal International Inclusive Education. Vol. 20, No. 10, (2016).

[5] Trikoler, Desai, El Masri Amira, ": The Hunt for New Canadians Begins in the Classroom: The Construction and Contradiction of Canadian Policy Discourse on International Education.," Journal Globalisation, Societis, and Education., vol. Vol. 15, No. 5, 2017.

[6] Andheska H.: Exclusion and inclusion in Daily Metropolitan Rubric Kompas: Critical Discourse Analysis Based on Theu Van Leeuwen's. Journal Bahastra, vol. 34, pp. 5-6, (2015).

[7] Khuriyati: Discourse Analysis of the News Text of Demands for Disbandment of FPI in SKH Kompas February 2012 Edition," Faculty of Da'wa UIN Sunan Kalijaga, Yogyakarta, Thesis (2013).

[8] Leeuwen T.Van: Dicourse and Practice; New Tools for Critical Discourse Analysis. New York: Oxford University Press, Inc. (2008).

[9] Darma Y.A.: Critical Discourse Analysis. Bandung: Yrama Widya, (2009).

[10] Eriyanto: Discourse Analysis: Introduction to Media Text Analysis. Yogyakarta: LKIS, (2009).

[11] Tenriawali A.Yusdianti: The Representation Viictim of Violence in Tribun Timur Online News Text: Critical Discourse Analysis," Totobuang, vol. Vol. 6, No. 1, pp. 4 (2018).

[12] N.D.J. Panjaitan: Reporting on Kerosene Scarcity Cases in Java (Discourse Analysis Concerning Cases Kerosene Scar city in Java on Daily Kompas," Faculty of Social and Political, Science University of North Sumatera, Medan, Thesis (2008).

[13] Creswell J.W.: Research Design Qualitative, Quantiif, and Mixed Methods Approaches, 4th ed. California, United States of America: Sage Publications, Inc. (2014)

[14] Liputan6.com. (2014, November) [Online]. http://www.liputan6.com

[15] Liput6.com. (2016, Oktober) [Online]. http://www.liputan6.com 
